\title{
MANAGING WITH CLASSIFIED INFORMATION IN CRISES AND CURRENT MODELS IN THE REPUBLIC OF MACEDONIA
}

\begin{abstract}
Atanas Kozarev
Fakultet pravnih nauka, Evropski univerzitet, Skopje, Republika Makedonija
\end{abstract}

\section{(C) MESTE NGO}

JEL category: $\mathbf{H 1 2}$

\section{Apstrakt}

Upravljanje krizom predstavlja ključni cilj postojanja i funkcionisanja savremenih bezbednosnih sistema. $\mathrm{U}$ tom kontekstu, pojavljuju se divergentni bezbednosni problemi, nove oblasti i izazovi koji su povezani sa specifičnostima modela zaštite klasifikovanih informacija u uslovima krize. Fundamentalni stav bezbednosnih teorija i prakse zasniva se na činjenici da bezbednost klasifikovanih informacija predstavlja preduslov za uspešno funkcionisanje bezbednosnih institucija, osobito u uslovima krize. Predmet naučnog istraživanja rada se odnosi pre svega na društvene odnose koji su povezani sa bezbednošću klasifikovanih informacija; procese definisanja i upravljanje rizikom koji ugrožava tu bezbednost u uslovima krize i kriznog stanja. Poseban akcenat je stavljen na model koji je implementovan u Republici Makedoniji i koji obuhvata: fizičku, administrativnu, industrijsku i informatičku bezbednost poverljivih informacija. Menadžiranje klasifikovanim informacijama je kontinuiran proces bezbednosnih institucija koji garantira da poverljiva informacija neće biti objekt neovlašćenog pristupa i upotrebe. Destabilizovanje procesa menadžiranja (planiranje, organizacija, odlučivanje, rukovođenje, kontrola) klasifikovanim informacijama znači destabilizaciju bezbednosnog sistema države i ugrožavanje nacionalne bezbednosti i ustavnog poretka u celini. Cilj rada je da na naučno - teoretskom nivou analizira aktuelni model menadžiranja klasifikovanim informacijama, njegovu strukturu, cilj, kao i da oceni njegovu efektivnost u uslovima krize.

Adresa autora:

Ključne reči: klasifikovana informacija, kriza, bezbednosni

Atanas Kozarev sistem, nacionalna bezbednosti.

莑"' atanas.kozarev@eurm.edu.mk 


\section{Abstract}

Crisis management is the main reason that modern security systems exist and function. In this respect, divergent security issues, areas and challenges can occur concerning the specific characteristics of the classified information security model in times of crisis. The fundamental tenet in security theories and practice is based on the fact that classified information security is a prerequisite for the successful operation of security institutions, especially during crises. The subject of this research paper primarily refers to social relations connected to classified information security; the process of defining and managing risk that exacerbates security in a situation of crisis. A special stress is given to the model implemented in the Republic of Macedonia which encompasses the physical, administrative, industrial and IT security of classified information. Managing classified information is a continuous process for security institutions, which guarantees that classified information aren't subject to unauthorized access or use. If the managing process concernsing classified information (the planning, organization, decisionmaking, operation, control) is destabilized, then the country's security system will be destabilized endangering both national security and constitutional regime as a whole. The purpose of this paper is to analyze the current model for managing classified information, its structure and purpose from a scientific and theoretical perspective. In addition, it will evaluate its effectiveness in times of crisis.

Keywords: classified information, crisis, security system, national security

\section{UVOD}

Osamostaljivanje RM značilo je i početak procesa demokratizacije društva - ekonomskog i političkog sistema, a time i izgradnju bezbednosnog sistema $u$ saglasnosti sa kriterijuma i standardima NATO-alijanse. Ovo čvrsto opredelenje političkog rukovodstva ugrađeno je u temelje nove bezbednosne arhitekture konstruisane od reformisanih bezbednosnih institucija. Pravni okvir za uspostavljanje i unapređivanje novog bezbednosnog sistema proizlazi od brojnih međunarodnih i domaćih dokumenata u domenu bezbednosti i odbrane. Na političkom nivou od velikoga značaja bilo je uspostavljanje diplomatskih odnosa između RM i EU 1995. godine, a u veoma kratkom periodu i uspostavljanje i obezbeđivanje članstva u programu FARE. U 1997. godini Vlada RM je potpisala Sporazum o saradnji sa EU, a 1998. godine Parlament RM doneo je Deklaraciju o razvoju odnasa sa EU. Tokom 2000. godine $u$ Zagrebu, RM je parafirala Sporazum o stabilizaciji i asocijaciji sa EU, što je dovelo do toga da u 2004. godini dolazi do zaključivanja Dogovara o stabilizaciji i asocijaciji sa EU. „Republika Makedonija kao deo Zapadnog Balkana u kontinuitetu i sa ubrzanim intenzitetom razvija svoje odnose sa Alijansom i njenim članicama, koji se zasnivaju na poštovanju i garanjciji ustavnih prava, doslednoj primeni međunarodnih evropskih standarda, vladavini prava i pravnoj državi, demokratizaciji institucija u sistemu podele vlasti itd." (Kozarev, 2012). Ono što daje poseban značaj velikom društvenom projektu nazvanom "evroatlantska integracija“ je to što za kamentemeljac ima ne pragmatični ekonomski, politički ili odbranbeni aspekt, nego upravo aspekt ljudskih sloboda i prava (Kambovski, 2007). Jedna od ključnih uloga moderne države je u dodeli i zaštiti prava i sloboda građana. Na sličan način, Ugovor iz Amsterdama upućuje Evropsku uniju da „očuva I razvije zonu slobode, bezbednosti i pravde“" (Hiks, 2007).

$\mathrm{U}$ kontinuitetu sa ovom političkom agendom i saradnjom sa evropskim institucijama, izvršene su i brojne reforme u bezbednosti i odbrani, čime je postignut pozitivan dekor za realiziranje strateškog nacionalnog interesa - članstvo u NATO-alijansi. $U$ tom cilju je Skupština RM 23.12.1993. godine donela Rešenje o ulasku RM u članstvo Severnoatlantske dogovorne organizacije - NATO. Posle toga dolazi do niza značajnih aktivnosti na tom putu, kao što su pristupanje Programu partnerstva za mir (1995. godine), članstvo u Severnoatlantskom savetu za saradnju - kasnije imenovan kao Evroatlanski partnerski savet (1997. godine), potpisivanje Ugovora RM-NATO za tranzitiranje snaga IFOR/SFOR kroz teritoriju RM (1995. godine), potpisivanje Sporazuma bezbednosnog aranžmana između RM i NATO-a, otvaranje makedonske kancelarije za veze sa NATO-om, sa sedištem u Briselu, prijem RM u Komitet za vojno 
planiranje i analizu (1997. godine) i niz drugih aktivnosti.

Isto tako, od velike važnosti bili su nacionalni dokumenti u funkciji ovih namera, kao što su: Nacionalna koncepcija za bezbednost i odbranu i Strategija za odbranu. Koncepcija za bezbednost i odbranu opredeljuje stavove i izražava poglede RM oko njenih nacionalnih interesa, njenog bezbednosnog okruženja i politike za nacionalnu bezbednost, kao i ciljeve, smerove, domene i instrumente njenog ostvarivanja. Ova koncepcija utvrđuje i stavove u odnosu odbranu, menadžiranje kriznim situacijama, a posebno se zalaže za optimizaciju bezbednosnih resursa, organizacije i smerova uvećavanja mogućnosti i spremnosti RM da odgovori izazovima, rizicima i opasnostima po bezbednost zemlje.

Strategija odbrane utvrđuje da se izgradnja i dalji razvoj sistema u odbrani zasnivaju na nedeljivosti, neotuđivosti i neprenosivosti suvereniteta RM, kao i na nepovredivost granica i teritorijalnog integriteta, uokvirujuči funkciju oružanih snaga za zaštita teritorijalnog integriteta i nezavisnost RM posebno time što niko nema pravo da prizna okupaciju RM ili njenog dela.

Kontinuirana nacionalna opredeljenost prema evroatlantskim strukturama i uspostavljanje institucionalnih i dogovornih odnosa sa NATO-om bilo je uslov za kontinuiranu razmenu klasifikovanih informacija. U tom cilju, odmah po potpisivanju Bezbednosne saradnje između RM i NATO 1996. godine, sa sedištem u Ministarstvu odbrane formirana je Služba za recipročnu bezbednost za zaštitu informacija. Za bezbednosnu distribuju klasifikovanih informacija do krajnih korisnika u ovoj službi je formiran Centralni registar, dok su u Ministarstvu unutrašnjih poslova i Ministarstvu spoljnih poslova formirani podregistri. U 2002. godini, Vlada RM donela je odluku o formiranju Nacionalnog bezbednosnog autoriteta RM u NATO kontekstu, kao stručne službe vlade. Kao rezultat ovog koraka proizlazi proces reformisanja bezbednosnog sistema u odnosu na klasifikovane informacije. Pravni okvir ove reforme zaokružuje se donešenjem Zakona o klasifikovanim informacijama, čime se uređuju klasifikacija informacija, uslovi, kriterijumi, mere i aktivnosti koje se preuzimaju za njihovu zaštitu, prava, obaveze i odgovornosti kreatora i korisnika klasifikovanih informacija, međunarodna razmena, kao i druga pitanja u vezi sa klasifikovanim informacijama. Formirana je i Direkcija za bezbednost klasifikovanih informacija.

Ovaj tempo je omogućio da se razvije jedna veoma značajna sfera bezbednosti kao nacionalni strateški interes, čime se RM spremno suočava sa globalnim bezbednosnim izazovima koje imaju ozbiljan uticaj na politku nacionalne bezbednosti i na sistem bezbednosti kao celinu. Time zaštita klasifikovanih informacija u vreme kriza dobija veliku praktičnu važnost za efikasno funkcionisanje bezbednosnog sistema. Sistem upravljanja kriznim situacijama obuhvata i sakupljanje informnacija, procenu i analizu situacije, utvrđivanje ciljeva i zadataka kao i razvoj i sproveđenje neophodnih aktivnosti za prevenciju, rano predupređenje i upravljanje sa krizom. Zakonom za upravljanje krizom (Sobranie, 2005), uređuje se sistem upravljanja krizama u RM čime se regulišu organizacija $i$ funkcionisanje, odlučivanje i upotreba resursa, komunikacije, koordinacija, saradnja, procena ugroženosti bezbednosti države, planiranje i finansiranje i niz drugih pitanja vezani za sistem upravljanje sa krizama.

Upravljanje krizama postaje relevantan elemenat sistema za nacionalnu bezbednost države koji je u permanentnoj funkciji razvijanja i unapređivanja interesa nacionalne bezbednosti. Time su apostrofirani važni bezbednosni problemi, područja i izazovi od strateškog interesa za državu, realizacije specifičnog modela zaštite klasifikovanih informacija u uslovima krize.

\section{TEORETSKO - KATEGORIJALAN DIZAJN MODELA KLASIFIKOVA- NIH INFORMACIJA I NJIHOVA ZAŠTITA}

Pojam "klasifikovana informacija" u sadržinskom smislu, u sebi inkorporiše pet različnih vrsta informacija: "državna tajna", "strogo poverljiva informacija", "poverljiva informacija", "interna informacija," kao i "klasifikovane informacije stranih država i međunarodnih organizacija".

Klasifikovana informacija sa stepenom "državna tajna" je informacija čije bi neovlašćeno otkrivanje prouzrokovalo ugrožavanje i nanošenje 
nepopravljivih šteta trajnim interesima Republike Makedonije.

Klasifikovana informacija sa stepenom "strogo poverljivo" je informacija stvorena od državnih organa, jedinica lokalne samouprave i drugih institucija koja je od značaja za javnu bezbednost, odbranu, inostrane poslove $\mathrm{i}$ bezbednosne $\mathrm{i}$ obaveštajne aktivnosti organa državne uprave Republike Makedonije, čije bi neovlašćeno otkrivanje prouzrokovalo izuzetno ozbiljnu štetu vitalnim interesima Republike Makedonije.

Klasifikovana Informacija sa stepenom "poverljivo" je informacija stvorena od državnih organa, organa jedinica lokalne samouprave i drugih institucija , koja je od značaja za javnu bezbednost, odbranu, inostrane poslove i bezbednosne i obaveštajne aktivnosti organa državne uprave Republike Makedonije, čije bi neovlašćeno otkrivanje prouzrokovalo ozbiljnu štetu važnim interesima Republike Makedonije.

Klasifikovana informacija sa stepenom "interno" je informacija čije bi neovlašćeno otkrivanje prouzrokovalo štetu radu državnih organa, jedinicama lokalne samouprave i drugim institucijama koje su od značaja za javnu bezbednost, odbranu, inostrane poslove i bezbednosne i obaveštajne aktivnosti organa državne uprave Republike Makedonije.

Klasificirana informacija stranih država i međunarodnih organizacija, u osnovi je informacija druge države ili međunarodne organizacije, koja je proizašla po sili određenog međunarodnog dogovora, u kome je Republika Makedonija dogovorna strana.

Imajući u vidu definicije pojedinih vrsta klasifikovanih informacija, može se konstatovati da je zajednička karakteristika za sve njih zaštita određenog državnog interesa kako od nezakonite dostupnosti određenoj informaciji, tako i od nezakonite upotrebe iste.

Bezbednosni rizik je mogućnost narušavanja bezbednosti klasifikovane informacije u opredeljenom bezbednosnom pojasu, bezbednosnoj ili administrativnoj zoni. Narušavanjem bezbednosti klasifikovane informacije nanosi se šteta interesima države: vitalni, trajni i važni nacionalni interesi.

Zbog širokog spektra pretnji i opasnosti koje mogu ugroziti bezbednost klasifikovane informacije, posebno za vreme kriza i kriznih stanja, njena zaštita treba biti organizovana sistemski, institucionalno i kontinuirano. Zakonski model zaštite klasifikovane informacije, kao i brojni podzakonski akti, predviđaju sistem mera $\mathrm{i}$ aktivnosti i uključivanje organa i institucija koji imaju svoje nadležnosti $\mathrm{i}$ obaveze $\mathrm{u}$ oblasti garantovanja sigurnosti klasifikovane informacije od nezakonskog pristupa istoj. Bezbednost klasifikovane informacije je obezbeđena onda kada su neutralizovane, svedene na prihvatljiv minimum opasnoti i pretnje od fizičkih nosilaca informacije, od lica koja rade sa njom (informacijom), od prostora u kome se informacija čuva itd.

$\mathrm{Na}$ taj način, može se zaključiti da se pojmovi bezbednost klasifikovane informacije i zaštita klasifikovane informacije ponašaju kao delovi jedne celine, kao podsistem jednog sistema. Ostvarivanje određene vrste sigurnosti je pretpostavka ka zaštiti informacije, ali je ova poslednja moguća samo pri sistemskom obezbeđivanju svih vrsta bezbednosti. Zaštita i bezbednost klasifikovane informacije dovode se $u$ korelaciju i mogući su samo ukoliko pod pojmom bezbednost podrazumevamo multidimenziolni kompleks uspostavljenih normativnih principa, mera i aktivnosti koji će garantovati da klasifikovana informacija neće biti objekat nezakonskih pristupa i upotrebe. Zaštita klasifikovanih informacija ima za svoj krajnji cilj ostvarivanje njene bezbednosti i ona treba da bude izgrađena na sistemskoj osnovi koja će stvoriti stanje u kome će biti neutralizirane ili svedene na minimum moguće pretnje po bezbednost klasifikovane informacije.

Destabilizacija bezbednosti klasifikovane informacije znači destabilizaciju bezbednosnog sistema države i ugrožavanje njene nacionalne bezbednosti i ustavnog poretka u celini.

Iz tog razloga je pri razmatranju bezbednosnog rizika kao mogućnosti narušavanja bezbednosti klasifikovane informacije, korektnije koristiti pojam "rizici po bezbednost klasifikovane informacije", a ne "rizici za zaštitu klasifikovane informacije".

\section{KRIZA I KRIZNA STANJA - NORMATIVNI ASPEKAT}

Savremeni svet sa sobom je doneo, a i nameće sve složeniji sistem sa društvenim, prirodnim i 
tehničko-tehnološkim aspektima. Pretnje, opasnosti i rizici kao mogući i verovatni događaji mogu dovesti do velikh opasnosti i pretnji po bezbednost ljudi i sveukupne imovine na određenom prostoru (Pejanović, 2010). Globalna slika bezbednosti postaje sve kompleksnija. I sam pojam bezbednosti dobija nove dimenzije i globalni značaj. Poslednje decenije dvadesetog veka karakteriše veliki broj vanrednih situacija, izazvanih događajima antropogenog ili prirodnog porekla. One su imale znatan negativan uticaj na životne aktivnosti ljudi, funkcionisanje privrede, socijalnu sferu i prirodnu sredinu (Blagojević, 2009).

Pojam kriza ima svoje interdisciplinarno značenje zbog toga što različne naučne discipline daju njegovu definiciju u zavisnosti od prirode naučnog interesa. Tako, kriza ima ekonomski, sociološki, politički, bezbednosni, humani aspekat, pri čemu zakonitosti koje vladaju u ovim oblastima otkrivaju njenu složenu strukturu i prirodu. Kriza, kao pojava koja je karakteristična za celokupno postojanje čovečanstva, ima i svoja dva veoma značajna parametra:

- područje ili zona krize (pod čim se podrazumeva deo zemljine površine gde postoje manifestni pojavni oblici rizika, pretnji i opasnosti koji mogu ugroziti nacionalnu, individualnu i međunarodnu bezbednost) $\mathrm{i}$

- vreme ili period krize (pod čim se podrazumeva konkretni vremenski period pojavljivanja određene pretnje i opasnosti, odnosno vreme početka krizne situacije $i$ vreme okončavanja iste).

Kriza najčešće prolazi kroz sledeće etape:
a. Etapa upozoravanja
b. Etapa oštre krize
c. Etapa savladavanja krize
d. Etapa razrešavanja krize.

Poznavanje ovih faza je od velike važnosti za naknadnu distinkciju sa fazama menadžmenta, odnosno sa upravljanjem krizama, koje je zasnovano na pravnoj osnovi i obuhvata više elemenata (faza) u svojoj strukturi, i to:

- praćenje stanja, dejstava i pojava koje mogu dovesti do nastanka krize (preventivna aktivnost),

- izrada prognoza i procena ugroženosti od rizika i opasnosti za pojavu kriza i kriznih stanja (analize, preporuke i zaključci Grupe za procenu),

- rano upozoravanje i obaveštavanje učesnika u sistemu upravljanja i stanovništva,

- analiza kriza i definisanje alternativnih pravaca dejstvovanja,

- plansko, pravovremeno, svrsishodno i koordinirano donošenje odluka, smernica i preporuka za preuzimanje mera za upravljanje krizama,

- preuzimanje operativnih mera i aktivnosti za delovanje protiv krize, kao i protiv onih koji su je prouzrokovali i

- uspostavljanje stanja stabilnosti u državi.

Prema Zakonu o upravljanju krizama, kriza je pojava kojom su ugrožene osnovne vrednosti, trajni i vitalni interesi i ciljevi države, odnosno kojom su ugroženi ustavni poredak i bezbednost Republike. Sa druge strane, pod pojmom krizno stanje se podrazumeva stanje nastalo kao posledica rizika i opasnosti koji mogu ugroziti dobra, zdravlje i živote ljudi i životinja i bezbednost Republike, za čiju je prevenciju i/ili upravljanje potrebna upotreba većeg obima resursa. Znači, pod zakonskom definicijom pojmova "kriza" i "krizno stanje" podrazumevaju se postojeće ili očekivane promene i ugrožavanje osnovnih vrednosti i nacionalnih interesa, kao i ljudskog života, koje su pre svega prouzrokovane od ljudi, ali $\mathrm{i}$ od prirodnih pojava koje narušavaju ili ugrožavaju život, zdravlje i imovinu građana, teritorije, neposredne okoline, kulturne i materijalne vrednosti države. Imajući u vidu tipizaciju kriza (unutrašnja, spoljna, ekonomska, tehnološka, informacijska, politička, ekološka itd.), u normativnom smislu, razlikujemo sledeće vrste ugrožavanja:

- Ugrožavanje bezbednosti Republike;

- Ugrožavanje života ljudi, životinja i biljaka;

- Ugrožavanje imovine i drugih materijalnih dobara većeg obima;

- Ugrožavanje stabilnosti, funkcionisanja države i njenog ustavnog poretka utvrđenim Ustavom, za koje ne postoje uslovi za proglašavanje ratnog ili vanrednog stanja.

Međutim, u svim ovim situacijama postoji konceptulna razlika između stanja kada kriza postoji i stanja kada postoji krizno stanje. Ova dva pojma imaju dijalektičku uzročno-posledičnu vezu: kriza (kao razlog) i krizno stanje (kao 
posledica realno nastale krize ili pretnje da će nastupiti kriza). U svakom slučaju može se reći da ova dva pojma nisu sinonimi jednog istog stanja. $\mathrm{U}$ odnosu na odlučivanje $\mathrm{i}$ upotrebu resursa $u$ vreme kriznog stanja, prema zakonskim normama, Vlada donosi odluku o postojanju kriznog stanja, određuje područje zahvaćeno kriznim stanjem i aktivira mehanizme za razreševanje kriznog stanja. O donesenoj odluci Vlada odmah obaveštava Skupštinu i predsednika Republike. Odluka o postojanju kriznog stanja ne može trajati duže od 30 dana. Ukoliko krizno stanje nastavi da traje više od 30 dana, Vlada treba da zatraži od Skupštine odobrenje o produžavanju roka ili treba da predloži proglašenje ratnog ili vanrednog stanja. $U$ odluci Vlade za upotrebu resursa organa državne uprave, organa opština i grada Skopja, mora se voditi računa da se isti upotrebe:

- proporcionalno prirodi i intenzitetu kriznog stanja;

- razumno, saglasno karakteru krize i

- ozbiljno saglasno jačini i obimu krize.

Odluku o upotrebi resursa teritorijalnih protivpožarnih jedinica Republike Makedonije i njenih republičkih snaga za zaštitu i spasavanje donosi direktor Direkcije za zaštitu i spasavanje. Isto tako, posebnu ulogu u izvršavanju poslova u oblasti upravljanjanja krizama ima i Centar za upravljanje krizama, koji izvršava aktivnosti koje se odnose na:

- obezbeđivanje kontinuiteta u međuresorskoj i međunarodnoj saradnji, konsultacijama i koordinaciji u upravljanju krizama;

- izrada i ažuriranje jedinstvene procene rizika i opasnosti po bezbednost Republike;

- predlaganje mera i aktivnosti za razrešavanje kriznog stanja i

- izvršava i druge poslove utvrđene zakonom.

Centar je nosilac ukupne podrške (stručne, organizaciske, administrativne i druge) Upravljačkog komiteta i Grupe za procenu. U cilju preduzimanja mera i aktivnosti za prevenciju i rano upozoravanje u slučaju kriznih stanja, svi učesnici u sistemu upravljanja krizama, saglasno zakonima i drugim propisima, dužni su da obezbede kontinuiranu i međusobnu komunikaciju, koordinaciju i saradnju na polju prikupljanja podataka i informacija, njihovu analizu, dostavljanje $\mathrm{i}$ informisanje o rizicima $\mathrm{i}$ opasnostima koji mogu ugroziti bezbednost Republike.

\section{BEZBEDNOSNI RIZICI - PRETNJA PO BEZBEDNOST INFORMACIJA I EFIKASNOST BEZBEDNOSNOG SISTEMA}

Rizik je verovatnoća nastupanja štetne posledice u slučaju izlaganja opasnostima (Mijalković \& Keserović, 2010). Bezbednosni rizik je kalkulisana prognoza nastajanja negativnih događaja (opasnosti) koji uzrokuju štete t.j. gubitke, odnosno kalkulisanih prognoza nastajanja pozitivnih događaja (prilika/šansi) koje nam donose koristi (Milutinović, 2013). Živimo u turblentnom i rizičnom vremenu. Svakodnevno se suočavamo sa brojnih izazovima i pretnjama koje kroz najrazličitije oblike ugrožavju individualnu (humanu), nacionalnu, regionalnu i međunarodnu bezbednost u celini. Rizici i konflikti otvaraju nova kriminogena, viktimogena i patogena žarišta od kojih nastaju nova sofisticirani pojavni oblici (fenomenologija) kriminalnih i patoliških pojava, neki čak i sa vrlo složenom etiološkom strukturom (Kozarev A. 2013)

Rizici i opasnosti po bezbednost Republike Makedonije jasno su utvrđeni u Nacionalnoj koncepciji za bezbednost i odbranu. U njoj stoji: „i pored toga što na duži rok ne postoji opasnost od konvencionalnog rata u Evropi, raspad bipolarnog sveta, recidivi i posledice globalizacije, nacionalna, verska, veliko-državna i teritorijalna konfrontacija - su potencijalni i realini rizici i opasnoti koji mogu dovesti do kriza i konflikta“. Kao rizike i opasnosti po bezbednost Republike Makedonije možemo navesti:

- moguće manifestacije ekstremnog nacionalizma, rasna i verska netrpeljivost;

- oblike i aktivnosti povezane sa međunarodnim terorizmom, organizovanim kriminalom, nelegalnom migracijom, nelegalnom trgovinom droge, oružja, ljudi, strategiskim i materijalima sa dvojnom namenom, kao i posledice od upotrebe sredstava za masovno uništenje;

- posedovnje velikih količina ilegalnog oružja;

- tranzicijske probleme, kao što su: korupcija, urbani terorizam, teški oblici kriminala, uključujuči ucene, reketiranja, ubistva i 
napade po imovinu građana, ekonomski kriminal, poresku evaziju, nedovoljan razvoj institucija demokratskog sistema, probleme u funkcionisanju sudstva, socijalne probleme i nezaposlenost;

- aktivnosti inostranih specijalnih službi usmerene ka pogoršanju bezbednosnog stanja, a time i usporavanje demokratskih integrativnih procesa, posebno onih ka NATO i EU;

- posledice sukoba interesa pri korišćenju izvora i puteva strategijskih energenata, kao i otežavanje i blokiranje njihovog uvoza u Republiku Makedoniju;

- elementarne i druge nepogode, tehničkotehnološke katstrofe, zarazne bolesti ljudi i životinja prouzrokovane od domaćih i/ili spoljnih činilaca;

- kompjuterski kriminal, pirateriju i zloupotrebu informatičke tehnologije, posebno u delu ličnih podataka građana, poslovne, službene i državne tajne;

- degradaciju i uništavanje životne sredine.

Upravljanje bezbednosnim rizicima i pretnjama predstavlja složeni sistem aktivnosti u kojima učestvuju brojne institucije bezbednosnog sistema. Upravljanje rizicima kao posebna vrsta upravljačke delatnosti i komponenta strategijskog rukovođenja podupire se na bazičnim karakteristikama i etapama upravljačkog procesa (donošenje odluka, planiranje, organizacija, motivacija i kontrola). Upravljanje rizicima je proces identifikovnja, analiza i ocena rizika i preuzimanje dejstava za njihovo smanjivanje do određenog dozvoljenog nivoa. Imajuči u vidu princip teorije upravljanja rizicima da rizik kao celina ne može biti eliminisan, neophodno je da se upvravlja istima, odnosno da rizici budu identifikovani, analizirani, procenjeni i tretirani adekvatnom strategijom. Tehnologija upravljanja rizicima u oblasti bezbednosti, u sebi obuhvata sledeće aktivnosti:

- Identifikacija rizika

- Analiza i ocena rizika

- Tretiranje rizika

- Monitoring i kontrola rizika.

\section{IDENTIFIKACIJA RIZIKA KOD POJEDINIH VIDOVA BEZBEDNOSTI KLASIFIKOVANIH INFORMACIJA U USLOVIMA KRIZE}

Opšto je rečeno da bezbednosni rizik pretstavlja mogućnost narušavanja bezbednosti klasifikovanih informacija čime se nanose štetne posledice po državne interese u celini. Informacije koje su predmet klasifikacije odnose se na javnu bezbednost, odbranu, inostrane poslove, bezbednosne obaveštajne i kontraobaveštajne aktivnosti organa državne uprave Republike Makedonije, sistemi, uređaji, projekti i planovi od značaja za Republiku Makedoniju. Procena rizika uključuje primenu više logičkih sistematičnih metoda za: komuniciranje i konsultacije tokom ovog procesa; uspostavljanje organizacionog koteksta za identifikaciju, analizu, procenu, tretman i kontrolu rizika vezanih za aktivnosti, proizvode, funkciju ili proces i adekvatno izveštavanje arhiviranje $u$ vezi sa rezultatima procene (Keserović, 2011).

Upravljanje rizicima kod pojedinih vidova bezbednosti klasifikovanih informacija u uslovima krize predstavlja proces identifikacije, analize, ocene, tretiranja, monitoringa i kontrole bezbednosnih rizika. Kao složeni proces javlja se kao deo, segment, sveukupnog procesa upravljanja rizicima u oblasti bezbednosti. Zato je pre svega neophodno odrediti bezbednosne pretnje i opasnosti za bezbednosni sistem u celini i u tim okvirima identifikovati pretnje od rizika po bezbednost klasifikovanih informacija u uslovima krize. Na taj način proces upravljanja rizicima po bezbednost klasifikovanih informacija u uslovima krize doprinosi povećanju efektivnosti bezbednosnog sistema države u uslovima krize. Kriterijumi koji se posebno uzimaju u obzir pri utvrđivanju mera za zaštitu klasifikovanih informacija su: stepen klasifikacije, obim i forma klasifikovanih informacija i procena pretnje po bezbednost klasifikovanih informacija. Za ostvarivanje zaštite klasifikovanih informacija preuzimaju se mere i aktivnosti administrativne, fizičke, informatičke i industrijske bezbednosti, kao i bezbednost lica (ili personalna bezbednost). 


\subsection{Administrativna bezbednost klasifikovanih informacija}

Administrativna bezbednost se sastoji od sledećih mera i aktivnosti:

- Utvrđivanje stepena i obeležavanje odnosno označavanje klasifikovanih informacija;

- Prijem i evidencija klasifikovanih informacija;

- Čuvanje i rukovanje upotreba klasifikovanih informacija;

- Reprodukcija, prevodi i izvodi klasifikovanih informacija i određivanje broja primeraka i korisnika;

- Kontrola i koriščenje klasifikovanih informacija u procesu raspoređivanja i rasprostranjivanja;

- Sprečavanje neovlaščenog iznošenja, odnosno objavljivanje klasifikovane informacije i narušavanje bezbednosti klasifikovanih informacija;

- Sprečavanje otkrivanja tajnosti klasifikovanih informacija i

- Otstranivanje i uništavanje klasifikovane informacije.

\subsection{Fizička bezbednost klasifikova- nih informacija}

Fizička bezbednost se sastoji od sledećih mera i aktivnosti:

- Procena mogućih narušavanja bezbednosti klasifikovanih informacija putem nasilnih upada ili neovlašćenih pristupa, upotreba i uništavanje klasifikovanih informacija;

- Određivanje bezbednosnog pojasa oko objekta; određivanje bezbednosnih i administrativnih zona;

- Organizovanje fizičkog obezbeđivanja i primena tehničkih i drugih sredstava za obezbeđenje objekata i prostorija u kojima se nalaze klasifikovane informacije;

- Izdavanje dozvola za pristup u objekte i prostorije;

- Kontrola ulaza, kretanja i izlaza lica i vozila za prenos klasifikovanih informacija i

- Prenos klasifikovanih informacija van bezbednosnih zona.

\subsection{Bezbednost lica}

Mere i aktivnosti bezbednosti lica su:
- Određivanje ovlašćenih lica za rad i postupanje sa klasifikovanim informacijama;

- Odgovorno postupanje sa klasifikovanim informacijama;

- Bezbednosna provera;

- Izdavanje bezbednosnog sertifikata;

- Izdavanje dozvola za pristup klasifikovanim informacijama i provera i

- Ocenjivanje sposobnosti za postupanje sa klasifikovanim informacijama.

\subsection{Informatička bezbednost klasifikovane informcije}

Mere i aktivnosti bezbednost klasifikovane informacije su:

- Certifikacija komunikacijsko - informacijskih sistema i procesa;

- Procena o mogućem narušavanju bezbednosti klasifikovane informacije upadom $u$ informatički sistem i upotrebi $i$ uništavanju klasifikovane informacije njenom obradom i čuvanjem u komunikacijskom iinformacijskom sistemu;

- Utvrđivanje metoda i bezbednosnih procedura za prijem, obradu, prenos, čuvanje i arhiviranje klasifikovanih informacija $u$ elektronskoj formi;

- Zaštita informacija pri procesuiranju i čuvanju klasifikovanih informacija u komunikacijsko informacijskim sistemima;

- Produkcija kripto ključeva i drugog kripto materijala;

- Kriptografska zaštita komunikacijskih, informacijskih i drugih elektronskih sistema preko kojih se pripremaju, prenose, obrađuju i arhiviraju klasifikovane informacije;

- Određivanje zona i prostorija zaštićenih od kompromitujućeg elektro-magnetnog zračenja i

- Instaliranje uređaja za čuvanje klasifikovanih informacija.

\subsection{Industrijska bezbednost klasifikovane informacije}

Mere i aktivnosti industrijske bezbednosti su:

- Zaštita od gubljenja ili otkrivanja tajnosti klasifikovanih informcija koje su sastavni deo industrijskog ugovora; 
- Izdavanje certifikata pravnim i fizičkim licima koja proizvode, upotrebljavaju ili imaju kontakt sa klasifikovanim informacijama u oblasti industrije;

- Zaštita od gubljenja ili otkrivanja tajnosti klasifikovanih informacija u konzorcijumima i mešovitim trgovačkim društvima sa inostranim fizičkim i pravnim licima;

- Obezbeđivanje zaštite pri transportu klasifikovanih informacija i uspostavljanje procedura za posetu objekata $\mathrm{i}$ industrijskih društva gde se proizvode, obrađuju i čuvaju klasifikovani materijli od strane fizičkih i pravnih lica iz druge države.

\section{ZAKLJUČAK}

Proučuvanje sistema bezbednosti klasifikovanih informacija potrebno je radi ocenjivanje njegove efektivnosti uopšte, a posebno u uslovima krize. $\mathrm{U}$ tom pravcu stvaraju se uslovi za projektovanje konkretne normativne, institucionalne i sadržajne izmene $u$ aktuelnom modelu zaštite informacija $u$ jednoj državi. Svaki sistem bezbednosti je suočen sa sofisticiranim opasnostima i pretnjama koje ugrožavaju bezbednost klasifikovanih informacija, a time i nacionalne, odnosno državne interese. $U$ radu je obrađen aktuelni model bezbednosti klasifikovanih informacija u Republici Makedoniji, pri čemu je potvrđena dijalektika pojmova informacija, klasifikovanih informacija i njihova bezbednost. Osnov za proučuvanje su lex specialis zakoni iz ove oblasti, kao i brojna podzakonska rešenja.
Može se zaključiti da sistem bezbednosti klasifikovanih informacija ima posebno mesto $i$ ulogu u sistemu nacionalne bezbednosti i da se nalazi u korelacionoj vezi sa sistemom upravljanja krizom. Ključna institucija u ovoj oblasti je Direkcija za bezbednosti klasifikovanih informacija koja implementira kriterijume, mere i aktivnosti za zaštiti klasifikovanih informacija, a koje se mnogu sistematizovati u četire grupe: za administrativnu bezbednost, za fizičku bezbednost, za bezbednosti lica i za infromatičku bezbednost.

Proces menadžiranja sistema bezbednosti klasifikovanih informacija u uslovima krize je složen i ima svoje zakonski utvrđene ciljeve, organizaciju i funkcionisanje nadležnih organa i tela (Upravljački komitet, Grupa za procenu, Centar za upravljanje krizama, Armija Republike Makedonije) i njihovu komunikaciju, koordinaciju i saradnju u uslovima krize. Nesporna je preventivna uloga efikasnog menadžiranja sa klasifikovanih informacijama u uslovima krize za ukupnu bezbednost društvenog sistema. Ta uloga može garantovati efikasnost sistema bezbednosti klasifikovanih informacija ukoliko se implementiraju elementi procesa menadžiranja rizicima u ovoj oblasti (odlučivanje, planiranje, organizacija, motivacija, kontrola), koje trebaju biti fokusirani na: identifikaciju rizika; analizu i ocenu rizika, tretiranje rizika za posebne vidove bezbednosti klasifikovanih informacija u uslovima krize; monitoring rizika i pravce za optimiziranje sistema zaštite klasifikovanih informacija $u$ uslovima krize.

\section{WORKS CITED}

Blagojević, M. (2009). Uloga MUP-a RS u uslovima mirnodopskih i vanrednih situacija (magistarska teza). Fakultet bezbednosti. Beograd.

Hiks, S. (2007). Politički sistem Evropske unije. Edicija Evropska unija. SLužbeni glasnik. Beograd.

Kambovski, V. (2007). Evolucija ustavnog Sistema RM u susret usvajanja ustavnog ugovora EU. Zbornik naučne rasprave održane 10.12.2007 godine. MANU. Skopje.

Keserović, D. (2011). Određivanje konteksta - početna i ključna faza procjene rizika korporacija. Zbornik radova. V Naučni skup: Dani bezbednosti. Fakultet za bezbjednost i zaštitu. Univerzitet Sinergija. Banja Luka.

Kozarev, A. (2012). Ljudska prava i njihov uticaj na evroatlatske perspektive Republike Makedonije, sa posebnim osvrtom na policijsku praktiku. Beograd: Institut za međunarodnu politiku i privredu.

Kozarev, A. (2013). Usatavne garancije i zaštita od diskriminacije u postupanju ovlaščenih slušbenih lica u Republici Makedoniji. Zbornik radova 1 Pravo i bezbednost. IV Međunarodni naučni skup: Multikulturalnost i savremno društvo. USEE. Pravne i poslovne akademska studije dr Lazar Vrkatić. Novi Sad.

Mijalković, S., \& Keserović, D. (2010). Osnovi bezbednosti. FBZ Banja Luka. 
Milutinović, M. (2013). Izazovi savremnog društva u bezbednosti. Zbornik radova 1 Pravo i bezbednost. IV Međunarodni naučni skup: Multikulturalnost i savremno društvo. USEE. Pravne i poslovne akademska studije dr Lazar Vrkatić. Novi Sad.

Pejanović, Lj., \& Kotur, I. (2009). Upravljanje vanrednom situacijom - nastanak pretnje i rizika. Zbornik radova. Naučni skup: Dani bezbednosti. Fakultet za bezbjednost i zaštitu. Univerzitet Sinergija. Banja Luka.

Sobranie. (2005, 05 04). Zakon za upravuvanje so krizi. Služben vesnik na Republika Makedonija. LXI(29). 1-13. Retrieved from http://www.slvesnik.com.mk/lssues/2B55BCB15891E144B555BA0302455CB6.pdf

Datum prve prijave: $\quad$ 23.01.2014.

Datum prijema korigovanog rada: $\quad 30.05 .2014$.

Datum prihvatanja članka: $\quad$ 23.06.2014.

\section{Kako citirati ovaj rad?}

Style - APA Sixth Edition

Kozarev, A. (2014, 07 15). Menadžment poverljivim informacijama u uslovima krize i aktuelni modeli u Republici Makedoniji. (Z. Čekerevac, Ed.) FBIM Transactions, 2(2), 204-213. doi:10.12709/fbim.02.02.02.20

\section{Style - Chicago Fifteenth Edition:}

Kozarev, Atanas. 2014. "Menadžment poverljivim informacijama u uslovima krize i aktuelni modeli u Republici Makedoniji." Edited by Zoran Čekerevac. FBIM Transactions (MESTE) 2 (2): 204213. doi:10.12709/fbim.02.02.02.20.

Style- GOST Name Sort:

Kozarev Atanas Menadžment poverljivim informacijama u uslovima krize i aktuelni modeli u Republici Makedoniji [Journal] // FBIM Transactions / ed. Čekerevac Zoran. - Beograd : MESTE, 07 15, 2014. 2 : Vol. 2. - pp. 204-213.

Style - Harvard Anglia:

Kozarev, A., 2014. Menadžment poverljivim informacijama u uslovima krize i aktuelni modeli u Republici Makedoniji. FBIM Transactions, 15 07, 2(2), pp. 204-213.

Style - ISO 690 Numerical Reference:

Menadžment poverljivim informacijama u uslovima krize i aktuelni modeli u Republici Makedoniji. Kozarev, Atanas. [ed.] Zoran Čekerevac. 2, Beograd : MESTE, 07 15, 2014, FBIM Transactions, Vol. 2, pp. 204-213. 